УДК 174:658:38:377:36

DOI: https://doi.org/10.37320/2415-3583/15.9

Липчанський В.O.

кандидат педагогічних наук, доцент Центральноукраӥнський національний технічний університет ORCID: https://orcid.org/0000-0002-3803-0518

Царенко I.O. кандидат економічних наук, старший викладач Центральноукраӥнський національний технічний університет ORCID: https://orcid.org/0000-0002-3591-7877

Пітел Н.С.

кандидат економічних наук, доцент Центральноукраӥнський національний технічний університет ORCID: https://orcid.org/0000-0001-9163-8998

\title{
ЕТИКА БІЗНЕСУ ЯК РІЗНОВИД ПРОФЕСІЙНОЇ ЕТИКИ В КОНТЕКСТІ СОЦІАЛЬНОЇ ВІДПОВІДАЛЬНОСТІ ПІДПРИЕМЦІВ ТА УПРАВЛІНСЬКИХ КАДРІВ
}

Досліджено і проаналізовано сучасний стан та вивчено досвід розвитку етики бізнесу як різновиду професійної етики в контексті соиіальної відповідальності підприємиів та управлінських кадрів в Украӥні. Визначено теоретичні засади етики бізнесу та організації системи соціальної відповідальності підприємиів та управлінських кадрів. Розкрито сутність ключових дефініцій дослідження та його понятійний апарат. Установлено особливості впровадження системи соиіальної відповідальності бізнесу в сучасних умовах господарювання. Констатовано, ще відповідальна поведінка особистості пов'язана із ситуативними та когнітивними чинниками. Визначено, щзо позитивні форми поведінки управляються найчастіше «особистими нормами», зумовленими, в першу чергу, самочікуванням індивіда, щчо виникають із сочіально поділюваних норм.

Ключові слова: етика бізнесу, професійна етика, підприємнищтво, особисті норми поведінки, відповідальність, соиіальна відповідальність управлінських кадрів, корпоративна соціальна відповідальність, етичний кодекс, етичні норми. 
Постановка проблеми. Складне й узагальнююче поняття, що відноситься до різних видів професійної діяльності, для яких розробляються свої етичні і моральні норми та правила у вигляді етичних формі кодексів підприємців, є суттю етики бізнесу [5].

Професійний кодекс етики - це система норм і правил, опрацьованих об'єднаннями для своїх членів як внутрішні моральні регулятори, якими фірми повинні керуватися під час складання корпоративних кодексів бізнесу, а також у своїй практичній професійній діяльності [15].

Дотримання господарюючими суб'єктами державного законодавства і виконання заходів державного регулювання свідчать про рівень розвитку ділової етики, що становить основу етики бізнесу. Цивілізовані ринкові відносини припускають, що повага до Закону $є$ найважливішим принципом, застосовуваним до ведення бізнесу: бізнес може плідно функціонувати тільки на основі розвинутого законодавства. 3 іншого боку, державні органи й їхні службовці повинні бути зацікавлені в тому, щоб діяти в інтересах бізнесу, забезпечуючи тим самим колективні інтереси підприємництва - захист від економічних злочинів, корупції, хабарництва. Для підвищення ділової моралі потрібні ефективна законодавча підтримка і система заохочення підприємницької етики, що в окремих країнах, і насамперед у США, отримала значний розвиток.

Професійна етика менеджера вимагає поваги думок інших людей, а отже, перед ухваленням рішення він повинен обмінятися ідеями і скористатися знаннями та досвідом колег. Проте, з огляду етичності, рекомендується обговорювати питання відкрито, щоб прийняті рішення були більш витриманими.

Аналіз останніх досліджень і публікацій. Питання етики бізнесу як різновиду професійної етики i менеджменту, їх наукового забезпечення, соціальної відповідальності підприємців та управлінських кадрів, проблеми та напрями їх вивчення знайшли своє відбиття у дослідженнях таких авторів, як: О.М. Аверін, А.А. Герасимчук, 3.I. Тимошенко, С.В. Шейко, I.Н. Герчикова, I.В. Житнюк, Б.І. Боровський, 3.В. Тимченко, Г.І. Золотухина, С. Туркін, К. Муздибаєв, І.Ю. Скибицька, Е.Г. Скибицький, Л.І. Скібіцька, О.М. Скібіцький, Г. Салліван, Дж. Роттер, У. Мішелл, В. Шеклтон, Е. Аронсон, К. Сандерсон, Ф. Хайдер, Дж. Сандберг, У.П. Кордейро, П.У. МакДжи, Дж. Аморос, Н. Босма, Дж. Вебер тощо.

Проте питання розшарування населення, поляризація його статків в умовах глобалізації, вірусних пандемій, локальних військових конфліктів і супутнього їм фінансування волонтерських рухів і економічної допомоги слаборозвиненим країнам вимагають додаткового висвітлення.

Мета статті полягає в аналізі стану та вивченні досвіду розвитку етики бізнесу як різновиду професійної етики в контексті організації системи соціальної відповідальності підприємців та управлінських кадрів.

Виклад основного матеріалу. Система етичних i правових норм і правил, що визначають стосунки господарюючих суб'єктів, а також між ними і державними органами, що здійснюють регулювання підприємницької діяльності, судовими органами, споживачами продукції, суспільством у цілому і становить предмет етики бізнесу [4].
У Кодексах етики бізнесу формулюються конкретні правила і принципи ділової поведінки стосовно окремої фірми (корпоративні кодекси етики), професії (кодекси професійної етики), а також до національних (стосовно ділової поведінки підприємців однієї країни) і міжнародних кодексів етики, орієнтованих на міжнародне ділове співтовариство [3].

Наприклад, міжнародний бізнес має своїм предметом ділові операції між підприємствами, що виступають незалежними суб'єктами ринку, а також внутрішньофірмові операції, здійснювані в рамках транснаціональних корпорацій, розташованих у різних країнах і взаємодіючих між собою, тому регулювання правових та етичних взаємин поширюється на зовнішньоекономічну діяльність у цілому й охоплює усі види операцій, здійснюваних фірмами: операції з купівлі-продажу товарів у матеріально-предметній формі, патентно-ліцензійні операції, міжнародний інжиніринг, міжнародні лізингові, туристські, франчайзингові операції, виробничотехнічні господарські зв'язки [14].

Етика бізнесу припускає вироблення визначених норм і правил, що поширюються на закордонну діяльність фірм, їхню поведінку на ринках приймаючих країн і дотримання законодавств цих країн; на припинення несумлінних методів ведення бізнесу - корупції, незаконного бізнесу, несумлінної конкуренції. Розробляючи власні корпоративні кодекси, фірми включають у них принципи і правила, засновані на положеннях, що містяться в кодексах професійної етики і міжнародних стандартах ділової поведінки.

Корпоративний кодекс містить положення, що відбивають правила (норми) і принципи ділової поведінки у певному підприємстві, відповідальність адміністрації стосовно працівників, зобов'язання з охорони навколишнього середовища.

Існують кодекси рекламної, банківської, адвокатської діяльності тощо. Їх розробляють союзи промисловців і підприємців, банкірські об'єднання, асоціації рекламних агентств тощо.

У 90-ті роки ХХ ст., коли проблеми бізнесу набули інтернаціонального характеру, першочергове значення стало надаватися створенню базового етичного кодексу для міжнародного ділового співтовариства. Міжнародні зводи правил, які регулюють поведінку корпорацій, були прийняті в рамках ООН, Міжнародної торговельної палати, Організації економічного співробітництва і розвитку - ОЕСР.

Одночасно в міжнародному діловому співтоваристві представниками ділових і наукових кіл США, країн Свропи й Азії розроблявся міжнародний етичний кодекс із назвою «Принципи ведення бізнесу», що був прийнятий у 1994 р. на черговому засіданні «Круглого столу групи» у Швейцарії.

Кожен кодекс етики бізнесу містить свою систему цінностей, свої принципи і норми ділової поведінки й ділової культури у цілому.

У діловій етиці поряд із договірними і правовими нормами важливу роль грають моральні регулятори, особливо коли відбувається узгодження приватних інтересів бізнесу і суспільних інтересів. До числа таких регуляторів відносяться: справедливість в оплаті праці працівників; забезпечення безпеки праці, що залежить від відношення підприємця до своїх працівників, від 
його поваги до людей і почуття гуманності; поєднання інтересів працівників своїх підприємств і соціальної політики, що проводиться в країні [9].

Стосовно культури партнерства, то сторони бізнесових взаємин повинні уникати в ділових відносинах порушення зобов'язань, обману, безвідповідальності, шахрайства, зловживання довірою партнера, не ущемляти права інших учасників ринку. Усі ці вимоги ділової етики грунтуються на принципах моральності та моралі, що виходять із: чесних і справедливих взаємин у бізнесі; сумлінного виконання зобов'язань; турботи про довірене майно; прагнення до налагодження тривалих стійких ділових зв'язків із партнерами; зміцнення взаємної довіри і досягнення взаємних інтересів у бізнесі; культури бізнесового партнерства, пред'явлення розумних вимог до партнера; культури ділової поведінки на ринку, дотримання звичаїв торгового обороту [18].

У поняття ділової етики входить поняття етики особистих відносин у підприємництві, що виявляються:

- у відносинах між радою директорів і акціонерами; оскільки акціонери є власниками капіталу компанії, принципи права на власність припускають, що їхні інтереси в ім'я справедливості повинні дотримуватися в першу чергу; однак у силу порушення етичних норм рада директорів може привласнювати собі більше прав;

- у відносинах між власниками акцій фірми і менеджерами. Найчастіше це пов'язано з контрактами про прийом, з участю менеджерів в акціонерному капіталі, зі ступенем їх самостійності. Особливо гострі конфлікти виникають між власниками акцій і менеджерами, коли власники контрольного пакету акцій вирішують продати їх, що спричиняє втрату менеджерами роботи. Тут постає питання особистої етики, а саме у відносинах між власниками акцій і найманих директорів (топ-менеджерів) компаній, які порушують норми етики і моралі під час управління компаніями (корупція і шахрайство)

Особиста етика менеджера вимагає поваги думок інших людей, а отже, перед ухваленням рішення він повинен обмінятися ідеями і скористатися знаннями та досвідом колег. Рекомендується обговорювати питання відкрито, щоб прийняті рішення були більш витриманими в етичному плані. Етика поведінки вимагає: дотримуватися визначених принципів; мати союзників серед рівних собі за посадою чи на стороні; не діяти через голову керівника за винятком випадків, коли він дійсно не правий; діяти завжди відкрито; відстоювати інтереси організації (фірми), не ставити особисті інтереси вище інтересів справи [10].

Від підприємців і управлінських кадрів вимагаються такі особисті якості:

- професіоналізм, компетентність, інформованість;

- передбачливість, уміння завоювати довіру;

- чесність, відкритість, упевненість у собі, почуття особистої гідності [12].

Визначимо постулати професійної етики підприємців - основу етичного кодексу підприємця:

- прагне до нововведень;

- не перекладає відповідальність за прийняття потрібного рішення на підлеглих;

- терпимий до недоліків інших людей;

- погоджує цілі підприємства 3 особистими цілями співробітників;
- нікого ніколи не принижує;

- має нескінченне терпіння [6].

Етичний кодекс підприємця, що здійснює індивідуальну діяльність, визначає його відношення до організації власної справи і забезпечення функціонування підприємства, тобто його власну систему цінностей; він вимагає дотримання підприємцем професійної, ділової й особистої етики. До таких вимог у сфері професійної етики відносяться: повага до партнера, контрагента i конкурента на ринку, повага до Закону в цілому [7].

Ділова культура - це система професійних знань і норм поведінки, що визначають відносини ділового партнерства, конфліктологію, правову й економічну культуру підприємця, культуру ділових відносин 3 органами адміністративного і державного управління [13]. Морально-етичні норми підприємництва включають: репутацію фірми в ділових відносинах; моральноетичні норми й обмеження в підприємницькій діяльності; урахування і дотримання морально-етичних принципів у стратегії і тактиці фірми; розроблення нормативів, що описують правила етики і систему загальних людських цінностей.

Ділова етика припускає:

1. Регулювання стосунків між господарюючими суб'єктами на основі дотримання зобов'язань $і$ норм зобов'язального права, щчо є частиною ичивільного права. Ці зобов'язальні відносини стосуються:

- виконання сторонами зобов'язань за контрактами, відшкодування збитків партнеру у разі виникнення збитку з вини однієї зі сторін; невключення в контракт зобов'язань і умов, що порушують бізнесову практику щодо вільної конкуренції;

- дотримання правил і норм, що стосуються проведення рекламних кампаній, застосування товарних марок, логотипів, знаків, дотримання заходів захисту інтелектуальної і комерційної власності;

- дотримання нормативних умов здійснення спільної діяльності, неухильне дотримання умов договору тощо.

2. Виконання правил і норм регулювання - заходів контролю державою над дотриманням законодавства, стандартів, постанов і нормативних актів $з$ ведення бізнесу. Державні органи стежать за виконанням підприємцями правил конкуренції; вводять обмеження у відношенні дискримінації в діловій практиці; вимагають дотримання законів про працю, про забруднення навколишнього середовища; здійснюють контроль над поданням фірмами звітності й інформації про свою діяльність (публікації річних звітів).

Дотримання ділової етики припускає чесне і сумлінне виконання законів і зобов'язань перед державою: сплату податків, виключення зловживань, дотримання вимог уповноважених державних органів; не допускати дій, які негативно впливають на конкуренцію шляхом використання домінуючого становища на ринку; рахуватися із заходами економічної, кредитної і податкової політики країни; враховувати наукову і технологічну політику країни, вимоги про захист навколишнього середовища.

3. Забезпечення законності бізнесу судовою системою, щзо повинна бути незалежною $і$ бути основою стабільності ділових відносин.

Судова система покликана створювати нормальні умови для дотримання договірних зобов'язань, уста- 
новлювати короткі терміни розгляду судових справ і арбітражних розглядів, нагляд за виконанням судових рішень за нормальної вартості судочинства.

4. Регулювання відносин між споживачами $i$ підприємницькими структурами з погляду ділової етики відповідно до принципів і правил реклами, щчо повинна носити чесний характер для повного задоволення попиту $i$ очікувань (запитів) споживачів щзодо кількості, якості, асортименту, новизни (інновачійності) технічних і споживчих характеристик послуг (товарів), які просуваються на ринок.

Головна вимога стосовно виробника - орієнтація на потреби і запити кінцевих споживачів. Ділова етика також вимагає чесного і сумлінного відношення до споживача у разі висування ним претензій до продавця з приводу рекламацій; із приводу термінів надання споживчих кредитів; з якості післяпродажного технічного обслуговування, забезпечення запасними частинами. Ділова етика припускає обов'язкове дотримання стандартів і вимог у відношенні сертифікації продукції, що забезпечують інтереси споживачів.

5. Стосунки бізнесу із суспільством, щуо носять, насамперед, морально-етичний характер.

Ділова етика безпосередньо зв'язана із соціальною відповідальністю компаній перед суспільством, що припускає обов'язок керівництва компанії опрацьовувати управлінські приймати рішення, спрямовані на підвищення рівня добробуту як суспільства у цілому, так і працівників самої компанії, та реалізовувати їх. Це знаходить вираження у здійсненні спеціальних обов'язкових виплат на соціальні потреби, у соціальні фонди, на соціальне забезпечення і страхування.

Згідно зі «Словарем современного русского литературного языка», відповідальність визначається як «покладене на когось або прийняте зобов'язання звітувати про які-небудь свої дії й приймати на себе провину за можливі їх наслідки» [16].

Поняття відповідальності безпосередньо взаємодіє 3 поняттям «самостійність». Коли рішення ухвалюється особисто суб'єктом дії, то на нього покладається загальна відповідальність. У групі відповідальність девальвується.

Усвідомлення відповідальності - це, насамперед, відбиття в суб'єкті буття соціальної необхідності, тобто розуміння змісту чинених дій і наслідків. Відповідальна поведінка особистості пов'язана, головним чином, із ситуативними, когнітивними чинниками. Позитивні форми поведінки управляються найчастіше «особистими нормами», зумовленими самоочікуванням індивіда, що виникають із соціально поділюваних норм.

Особисті норми поведінки пов'язані з образом «Я».

Соціальна відповідальність бізнесменів і керівників (найманих менеджерів) може вступати у протиріччя 3 юридичною відповідальністю. Наприклад, усупереч законам керівник знаходить засоби, здаючи в оренду приміщення, що перебуває на території підприємства, для погашення заборгованості працівникам по зарплаті. Таку поведінку керівника 3 чисто людських позицій можна розцінити як соціально відповідальну [1].

Однією з форм правового і морального забезпечення соціальної активності особистості є відповідальність за бездіяльність. Людина повинна почувати себе відповідальною не тільки за зроблене нею, а й за те, чого вона не зробила, хоча зобов'язана була це зробити. Колективна відповідальність, на думку західних фахівців-психологів, «розмиває» індивідуальну відповідальність, що в остаточному підсумку призводить до безвідповідальності.

Соціальну відповідальність слід розглядати як стійку особистісну властивість. Становлячи життєві плани, людина звичайно зважує, чи посильна їй ця мета або потрібно сподіватися на зовнішні сили, на інших людей.

Соціальна відповідальність бізнесу перед суспільством припускає також надання громадськості відкритої інформації про діяльність компанії, іiї ділові принципи і моральні цінності. Суспільство цікавиться, за рахунок чого накопичені кошти компанії й як використовуються отримані прибутки. Це сприяє формуванню суспільної думки про конкретну компанію і про бізнес у цілому.

Корпоративна соціальна відповідальність має на увазі також визначені добровільні дії компаній за рішенням соціальних проблем, не регульовані законом. Сюди відносяться добродійність, здійснення соціальних програм місцевого значення, добровільне припинення виробництва продукції у разі ії небезпеки для споживача.

Наявність інстанцій як таких є важливим чинником, що регулює не тільки індивідуальне, а й громадське життя. Кількість інстанцій, перед якими людина несе відповідальність, досить велика. Психологічною передумовою відповідальності є можливість вибору, тобто свідомої переваги певної лінії поведінки. Вибір може здійснюватися в ускладнених умовах, наприклад у конфліктних, де зустрічаються інтереси окремо взятої особистості, групи людей або суспільства. Відповідальність уважається найважливішою властивістю особистості. Якщо йдеться про прийняття соціальних норм поведінки, то зазвичай говориться про соціальну відповідальність особистості. Особливість ii полягає у тому, що іiі об'єктом є соціальні норми і рольові функції. Суб'єктом контролю може виступати як сама людина, так і їі соціальне оточення.

Висновки. Розвідки науковців свідчать, що деякі керівники використовують групове прийняття рішення для того, щоб уникнути відповідальності або розділити iiï 3 членами групи. Тому дуже важливою в практиці управління $є$ персональна відповідальність керівника за прийняття або неприйняття якого-небудь рішення. Усвідомлення відповідальності - це, насамперед, відбиття в суб'єкті буття соціальної необхідності, тобто розуміння змісту чинених дій і наслідків.

Відповідальність уважається найважливішою властивістю особистості. Якщо йдеться про прийняття соціальних норм поведінки, то зазвичай говориться про соціальну відповідальність особистості. Особливість ії полягає у тому, що ії об'єктом є соціальні норми й рольові функції. Суб'єктом контролю може виступати як сама людина, так і іiї соціальне оточення.

Відповідальна поведінка особистості пов'язана, головним чином, із ситуативними, когнітивними чинниками. Позитивні форми поведінки управляються найчастіше «особистими нормами», зумовленими самоочікуванням індивіда, що виникають із соціально поділюваних норм. 
Чим більше підприємців в Україні зацікавляться в тривалому та захоплюючому успіху, тим більше людей задумаються про проблеми етики взагалі та ділової етики зокрема. А зростання кількості людей, які поважають етичний кодекс, поставить нашу країну на один рівень із країнами, де давно існує цивілізований ринок. Пропонуємо в управлінні людським потенціалом підприємств розрізняти юридичну, моральну і соціальну відповідальність.
Питання розшарування населення світу на країни розвинуті і ті, що розвиваються, чи слаборозвинені; поляризація статків різних верств населення всередині країн в умовах глобалізації, техногенних і природних катастроф, вірусних пандемій, локальних військових конфліктів; проблеми фінансування волонтерських рухів і економічної допомоги слаборозвиненим країнам мають стати предметом подальших наукових розвідок розглянутої проблеми.

\section{Список використаних джерел:}

1. Аверин А.Н. Социальна политика и социальная ответственность предприятия. Москва : Альфа-Пресс, 2008.96 с.

2. Герасимчук А.А., Тимошенко 3.І., Шейко С.В. Філософські основи менеджменту і бізнесу : навчальний посібник. Київ : Свропейський ун-т, 2006. 111 с.

3. Герчикова И.Н. Деловая этика и регулирование международной коммерческой практики : учебное пособие. Москва : Консалтбанкир, 2002. 574 с.

4. Баранівський В.Ф., Скворцова Т.Г. Етика бізнесу : навчальний посібник. Київ : Паливода А.В., 2008. 200 с.

5. Житнюк И.В., Боровский Б.И., Тимченко З.В. Этика менеджмента / В.Н. Узунов (ред.). Симферополь : Таврида, 1997. 72 с.

6. Золотухина Г.И. Хозяйственная этика: избранные лекции : учебное пособие. Красноярск, 2000. 102 с.

7. Казакевич Г. Социальная ответственность: новые требования к бизнесу в постиндустриальную епоху. Персонал. 2002. № 2. C. 74-78.

8. Туркин С. Как выгодно быть добрым: Сделайте свой бизнес социально ответственным. Москва : Альпина Бизнес Букс, 2007. $381 \mathrm{c}$.

9. Корпоративная социальная ответственность: общественные ожидания / под ред. С.Е. Литовченко, М.И. Корсакова. Москва : Ассоциация менеджеров, 2003. 100 с.

10. Муздыбаев К. Психология ответственности : монография. Ленинград : Наука, 1983. 240 с.

11. Психология : учебное пособие / Э.Г. Скибицкий и др. Караганда : КарГТУ, 2014. 311 с.

12. Салливан Г., Роттер Дж., Мишелл У. Теория межличностных отношений и когнитивные теории. Москва : ПраймЕврознак, 2007. $128 \mathrm{c.}$

13. Скибицкий Э.Г., Скибицкая И.Ю. Коммуникативный аспект делового общения. Новосибирск : НГАСУ, 2019. 106 с.

14. Скибицкий Э.Г., Китова Е.Т. Управление конфликтами в профессиональной деятельности : учебное пособие. Новосибирск : НГТУ, 2019. 196 с.

15. Скібіцька Л.І. Соціальна відповідальність бізнесу, менеджерів і виконавців в антикризовому менеджменті. Корпоративно-соціальна відповідальність бізнесу - фактор сталого розвитку держсви : Міжнародна науково-практична конференція студентів, аспірантів та викладачів, 23-26 квітня 2012 р. : тези доп. Київ : Академія праці і соціальних відносин ФПУ, 2012. С. 42-45.

16. Скібіцький О.М. Психологія відповідальності у менеджменті людського потенціалу. Корпоративно-соиіальна відповідальність бізнесу - фактор сталого розвитку держави : Міжнародна науково-практична конференція студентів, аспірантів та викладачів, 23-26 квітня 2012 р. : тези доп. Київ : Академія праці і соціальних відносин ФПУ, 2012. С. 46-49.

17. Словарь современного русского литературного языка / под ред. К.С. Горбачевича. Москва ; Санкт-Петербург : Академия наук СССР, 1954. 1340 с.

18. Шеклтон В. Психология лидерства в бизнесе. Санкт-Петербург : Питер, 2003. 222 с.

19. Aronson, Elliot (2012) Social Psychology. New York : Prentice Hall. Pp. 106-108.

20. Heider, Fritz (1958) The Psychology of Interpersonal Relations. The Psychology Press. New York : Wiley.

21. Sanderson, Catherine (2010) Social Psychology. John Wiley \& Sons, Inc. 112 p.

22. Definition of Business Ethics. Investopedia. URL: http://www.investopedia.com/terms/b/business-ethics.asp\#ixzz4Zjd3JSgF

23. Sandberg, J. (2010) Business Ethics. URL: https://www.rep.routledge.com/article/L009

24. MacGee, P.W. (2012) The Ethics of Tax Evasion. Springer. 339 p.

25. Cordeiro, W.P. (2011) Entrepreneurial business ethics: A special case or business as usual? International Journal of Economics and Business Research. № 3(3). P. 241-252. URL: https://doi.org/10.1504/IJEBR.2011.040018

26. Amoros, J., \& Bosma, N. (2013) Global Entrepreneurship Monitor: 2013 Global Report. Babson Park, MA: Global Entrepreneurship Research Association. URL: https:/www.gemconsortium.org/report/gem-2013-global-report

27. Arora, B., \& Puranki, R. (2004) A review of corporate social responsibility. Development, 47(3), 93-100. URL: https://doi.org/ 10.1057/palgrave.development. 1100057

28. Hasnas, J. (1998) The normative theories of business ethics: A guide for the perplexed. Business Ethics Quarterly, 8(1), 19-42. URL: https://doi.org/10.2307/3857520

29. Persons, O. (2009) Using a corporate code of ethics to access students' ethicality: Implications for business education. Journal of Education for Business, 84(6), 357-366. URL: https://doi.org/10.3200/JOEB.84.6.357-366

30. Solymossy, E., \& Masters, J.K. (2002) Ethics through an entrepreneurial lens: Theory and observation. Journal of Business Ethics, 38(3), 227-241. Available at: https://doi.org/10.1023/A:1015832123366

31. Weber, J. (1990) Managers' moral reasoning: Assessing their responses in three moral dilemmas. Human Relations, 43(7), 687-702. URL: https://doi.org/10.1177\%2F001872679004300705

\section{References:}

1. Averyn A.N. (2008) Sotsyalna polytyka y sotsyalnaya otvetstvennost predpryyatyya [Social policy and social responsibility of the enterprise]. Moscow: Yzdatelstvo «Alfa-Press». (in Russian)

2. Herasymchuk A.A., Tymoshenko Z.I., Sheyko S.V. (2006) Filosofski osnovy menedzhmentu i biznesu [Philosophical foundations of management and business]. Yevropeys'kyy un-t. Kyiv: Vydavnytstvo Yevropeyskoho un-tu. (in Ukrainian) 
3. Herchykova Y.N. (2002) Delovaya etyka y rehulyrovanye mezhdunarodnoy kommercheskoy praktyky [Business ethics and regulation of international commercial practice]. Moscow: Konsaltbankyr. (in Russian)

4. Baranivskyy V.F., Skvortsova T.H. (2008) Etyka biznesu: Navchalnyy posibnyk [Business ethics: Textbook]. Kyiv: Vydavets «Palyvoda A.V.». (in Ukrainian)

5. Zhytnyuk Y.V., Borovskyy B.Y., Tymchenko Z.V. (1997) Etyka menedzhmenta [Ethics of management]. Symferopol: Tavryda. (in Russian)

6. Zolotukhyna H.Y. (2000) Khozyaystvennaya etyka [Economic ethics]. Krasnoyarsk: Krasnoyarskyy hos. un-t. (in Russian)

7. Kazakevych, G. (2002) Sotsialnaia otvetstvennost: novye trebovaniia k biznesu v postindustrialnuiu epokhu [Social responsibility: new business requirements in the post-industrial era]. Personal, 2, 74-78.

8. Turkyn S. (2007) Kak vyhodno byt dobrym: Sdelayte svoy byznes sotsialno otvet stvennym [How profitably is to be kind: Make your business socially responsible]. Moscow: Alpyna Byznes Buks. (in Russian)

9. Lytovchenko S.E., Korsakova M.Y. (eds.) (2003) Korporatyvnaya sotsyalnaya otvetstvennost: obshchestvennye ozhydanyya [Corporate social responsibility: public expectations]. Moscow: Assotsyatsyya menedzherov. (in Russian)

10. Kunashbek M. (1983) Psykholohyya otvetstvennostyn [Psychology of responsibility]. Lenynhrad: Yzdatelstvo «Nauka», Lenynhradskoe otdelenye. (in Russian)

11. Skybytskyy E.H., Ehorov V.V., Skybytskaya Y.U. (2014) Psykholohyya [Psychology]. Karaganda: KarGTU. (in Russian)

12. Sallyvan H., Rotter Dzh., Myshell U. (2007) Teoryya mezhlychnostnykh otnoshenyy y kohnytyvnye teoryy [Theory of interpersonal relationships and cognitive theories]. Moscow: Praym-Evroznak. (in Russian)

13. Skybytskyy É.H. (2019) Kommunykatyvnyy aspekt delovoho obshchenyya [Communicative aspect of business communication]. Novosybyrsk: NHASU. (in Russian)

14. Skybytskyy E.H., Kytova E.T. (2019) Upravlenye konflyktamy v professyonal'noy deyatel'nosty [Management of conflicts in professional activity]. Novosybyrsk: NHTU. (in Russian)

15. Skibitska L.I. (2012) Sotsial'na vidpovidal'nist' biznesu, menedzheriv i vykonavtsiv v antykryzovomu menedzhmenti [Social responsibility of business, managers and executors in the crisis management]. Korporatyvno-sotsial'na vidpovidal'nist' biznesu-faktor staloho rozvytku derzhavy: Mizhnarodna naukovo-praktychna konferentsiya studentiv, aspirantiv ta vykladachiv. (in Ukrainian)

16. Skibitskyy O.M. (2012) Psykholohiya vidpovidal'nosti u menedzhmenti lyuds'koho potentsialu [Psychology of responsibility in human resource management]: Mizhnarodna naukovo-praktychna konferentsiya studentiv, aspirantiv ta vykladachiv "Korporatyvno-sotsial'na vidpovidal'nist' biznesu - faktor staloho rozvytku derzhavy». (in Ukrainian)

17. Horbachevycha K.S. (ed.) (1954) Slovar sovremennoho russkoho lyteraturnoho yazyka [Dictionary of modern Russian literary language]. Moscow; Saint-Petersburg: Akademiya nauk SSSR. (in Russian)

18. Sheklton V. (2003) Psykholohyya lyderstva v byznese [Psychology of leadership in business]. Saint-Petersburg: Pyter. (in Russian)

19. Aronson, Elliot (2012) Social Psychology. New York: Prentice Hall, pp. 106-108.

20. Heider, Fritz (1958). The Psychology of Interpersonal Relations. The Psychology Press. New York: Wiley, 360 p.

21. Sanderson, Catherine (2010) Social Psychology. John Wiley \& Sons, Inc. 112 p.

22. Definition of Business Ethics. Investopedia. URL: http://www.investopedia.com/terms/b/business-ethics.asp\#ixzz4Zjd3JSgF

23. Sandberg, J. (2010) Business Ethics. URL: https://www.rep.routledge.com/article/L009

24. MacGee, P.W. (2012) The Ethics of Tax Evasion. Springer. 339 p.

25. Cordeiro, W.P. (2011) Entrepreneurial business ethics: A special case or business as usual? International Journal of Economics and Business Research, 3(3), 241-252. Available at: https://doi.org/10.1504/IJEBR.2011.040018

26. Amoros, J., \& Bosma, N. (2013) Global Entrepreneurship Monitor: 2013 Global Report. Babson Park, MA: Global Entrepreneurship Research Association. URL: https:/www.gemconsortium.org/report/gem-2013-global-report

27. Arora, B., \& Puranki, R. (2004) A review of corporate social responsibility. Development, 47(3), 93-100. URL: https://doi.org/ 10.1057 /palgrave.development. 1100057

28. Hasnas, J. (1998) The normative theories of business ethics: A guide for the perplexed. Business Ethics Quarterly, 8(1), 19-42. URL: https://doi.org/10.2307/3857520

29. Persons, O. (2009) Using a corporate code of ethics to access students" ethicality: Implications for business education. Journal of Education for Business, 84(6), 357-366. URL: https://doi.org/10.3200/JOEB.84.6.357-366

30. Solymossy, E., \& Masters, J.K. (2002) Ethics through an entrepreneurial lens: Theory and observation. Journal of Business Ethics, 38(3), 227-241. Available at: https://doi.org/10.1023/A:1015832123366

31. Weber, J. (1990) Managers' moral reasoning: Assessing their responses in three moral dilemmas. Human Relations, 43(7), 687-702. URL: https://doi.org/10.1177\%2F001872679004300705 


\section{Lypchanskyi Volodymyr, Tsarenko Ilona, Pitel Nataliia}

Central Ukrainian National Technical University

\section{BUSINESS ETHICS AS A VARIETY OF PROFESSIONAL ETHICS IN THE CONTEXT OF SOCIAL RESPONSIBILITY OF ENTREPRENEURS AND MANAGEMENT STAFF}

Business ethics as a variety of professional ethics is a complex and generalizing concept that refers to the various types of professional activities for which their ethical and moral norms and rules are developed in the form of ethical forms of codes of entrepreneurs. The issue of population stratification, the polarization of its wealth in the context of globalization, viral pandemics, local military conflicts and the accompanying funding of volunteer movements and economic assistance to underdeveloped countries, require additional coverage. In accordance with the goal, the following research objectives are defined: to determine the theoretical foundations of business ethics and organization of the system of social responsibility of entrepreneurs; to reveal the essence of key definitions of research (its conceptual apparatus); to establish features of introduction of system of social responsibility of business; to study the current state of development of business ethics and management in Ukraine. Business ethics requires a culture of business partnership a partnership based on trust, integrity, honesty, a sense of duty, in the ability to keep the word. The parties must avoid in business relations breach of obligations, fraud, irresponsibility, fraud, abuse of trust of the partner, not to infringe on the rights of other market participants. One of the forms of legal and moral support of social activity of the individual is the responsibility for inaction. Some leaders use group decision-making to avoid responsibility or to share it with group members. Therefore, it is very important in management practice to establish the personal responsibility of managers for making (not taking) a certain decision. Awareness of responsibility is, first of all, a reflection in the subject of being a social necessity, ie understanding the content of actions and consequences. Responsibility is considered the most important property of the individual. When it comes to the adoption of social norms of behavior, it is usually about social responsibility of the individual. Its peculiarity is that its object is social norms and role functions. The subject of control can be both the person himself and its social environment. Responsible personality behavior is related to situational, cognitive factors. Social responsibility of businessmen and managers (hired managers) may conflict with legal responsibility.

Key words: business ethics, professional ethics, entrepreneurship, personal norms of behavior, responsibility, social responsibility of management staff, corporate social responsibility, code of ethics, ethical norms.

JEL classification: A14, D64, M10, E64, E71 